\section{Lubricating Properties of Molecular Layers of Stearic Acid and Calcium Stearate on Metal Surfaces}

Folcowrng the work of Bowden, Gregory and Tabor $^{1}$, we have made friction-temperature measurements on mono-and multi-layers of calcium stearate and stearic acid on various metals. These authors stated that for each metal the transition from smooth to stick-slip sliding and a rise in the friction occurred at the melting or softening point of a surface film of metal soap produced by reaction with the fatty acid. It seemed, therefore, that in mixed films of soap and acid there should be fluctuations in the friction curve corresponding to the melting points of the substances present.

We deposited molecular layers of calcium stearate and stearic acid on copper, platinum and stainless steel by the Langmuir-Blodgett method $^{2}$ from a $10^{-4}$ molar solution of calcium carbonate. At $p H 6$ these layers contain 60 per cent soap and 40 per cent acid $^{3}$. We used the Bowden - Leben friction apparatus to study the frictional behaviour.

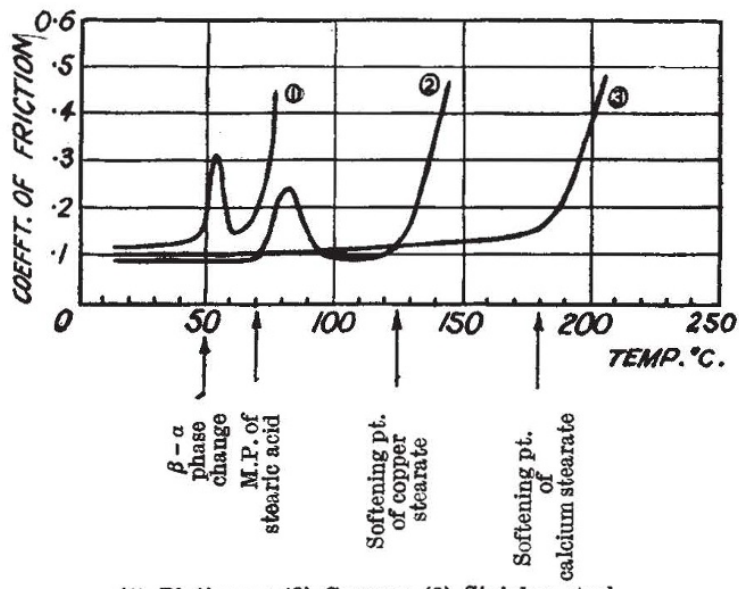

(1) Platinum; (2) Copper; (3) Stainless steel

The temperatures at which changes in friction occurred corresponded closely to known physical changes of the layer substance in bulk (see graph and table).

\begin{tabular}{|c|c|c|c|}
\hline Metal & $\begin{array}{c}\text { No. of } \\
\text { monolayers }\end{array}$ & $\begin{array}{l}\text { Transition } \\
\text { temperature } \\
\left({ }^{\circ} \mathbf{C} .\right)\end{array}$ & Remarks \\
\hline Platinum & $\begin{array}{l}1 \\
3 \\
5 \\
7 \\
9\end{array}$ & \begin{tabular}{ll}
\multicolumn{2}{l}{ No lubrication } \\
2ै0-25 & "ै0-60 \\
$40-45$ & 70 \\
$45-55$ & $75-85$
\end{tabular} & $\begin{array}{l}\beta \text { to } \alpha \text { transforma- } \\
\text { tion at } 54^{\circ} \mathrm{C} . \text { M.P. } \\
\text { stearic acid, } 69^{\circ} \mathrm{C} \text {. }\end{array}$ \\
\hline $\begin{array}{c}\text { Stainless } \\
\text { steel }\end{array}$ & $\begin{array}{l}1 \\
3 \\
4\end{array}$ & $\begin{array}{c}150-160 \\
170 \\
170-190\end{array}$ & $\begin{array}{l}\text { Softening point cal- } \\
\text { cium stearate, } 180^{\circ}\end{array}$ \\
\hline Copper & $\begin{array}{r}1 \\
3 \\
7 \\
9 \\
21\end{array}$ & $\begin{array}{cc}\text { No lubrication } \\
70 & \mathbf{1 2 5} \\
70 & \mathbf{1 2 5} \\
70 & \mathbf{1 2 5} \\
70 & \mathbf{1 2 5}\end{array}$ & $\begin{array}{l}\text { M.P. stearic acid, } \\
69^{\circ} \text {. Softening point } \\
\text { copper stearate, } \\
125^{\circ}\end{array}$ \\
\hline
\end{tabular}

With copper surfaces there are two fluctuations. The first, at the melting point of stearic acid, is not permanent and is thought to be due to the melting of the stearic acid, which, when liquid, is able to react with the surface, forming solid copper stearate. The friction then falls to its original low value and continues so until the softening point of copper stearate $\left(125^{\circ} \mathrm{C}.\right)$, above which temperature a permanent increase in friction occur's.

On stainless steel no frictional changes occur at the melting points of stearic acid or ferric stearate $\left(100-125^{\circ} \mathrm{C}.\right)$, but there is a transition at the softening point of calcium stearate $\left(180^{\circ} \mathrm{C}\right.$.). With platinum, a fluctuation occurs below the melting point of stearic acid. Similar fluctuations are observed with palmitic and octacosanoic acids on platinum at $45^{\circ} \mathrm{C}$. and $80^{\circ} \mathrm{C}$. respectively. These temperatures are very closely similar to the temperatures at which $\beta, \alpha$ phase changes were observed in X-ray studies of monolayers of these acids on gold surfaces by Dupré la Tour $^{4}$. It appears that the friction change is related to this phase transformation. There is also, as with copper, a sharp rise in friction at the melting points of the acids; but since no reaction can take place, no subsequent recovery occurs.

In general, each fluctuation corresponds to a softening or melting point of one of the constituents of the lubricating layer; but the frictional effects, and the number of layers required for lubrication, depend considerably on the nature of the underlying metal. Calcium stearate does not appear to lubricate copper and platinum, since with a mixed film, final breakdown of lubrication occurs at the same tem. perature as when pure stearic acid is spread on the surfaces $^{5}$. Yet calcium stearate appears to lubricate stainless steel up to its melting point. This anomaly may be related to the fact that it requires only one molecular layer to lubricate steel compared with the three and five layers for copper and platinum respectively.

It is hoped that future work with an electron diffraction camera will give more information on these points.

J. N. Gregory

$$
\text { J. A. SPINK }
$$

Section of Tribophysics,

Council for Scientific and Industrial Research, University, Melbourne, N.3.

Dec. 24.

${ }^{1}$ Bowden, F. P., Gregory, J. N., and Tabor, D., Nature, 156, 97 (1945). ${ }^{2}$ Blodgett, K., J. Amer. Chem. Soc., 57, 1007 (1935).

${ }^{3}$ Langmuir, I., and Schaefer, V. J., J. Amer. Chem. Soc., 58, 284 (1936) - Dupré la Tour, Ann. de Phy8., 18, 199 (1932).

Ballantyne, C. S. I. R., (Tribophysics) Report No. A 137 (1945).

\section{Hydrogen Bonding in Ice}

IN a recent communication in Nature $^{1}$, Prof. Max Born has discussed some features of the Raman spectrum of ice, more particularly in relation to the elastic constants. Since Prof. Born makes no use of the available infra-red measurements on ice $^{2}$ or of some earlier work on certain aspects of hydrogen bonding in ice, it seems worth while to recall some relevant data:

(1) Frequencies at $205-210$ and $601 \mathrm{~cm}^{-1}$ occur in the Raman spectrum of ice $^{3,4}$ (calculated as 172 and $718 \mathrm{~cm}^{-1}$ by Prof. Born from the elastic con. stants of ice) and are also found in liquid water ${ }^{3,4,5}$ less sharply defined at $\sim 175$ and $\sim 500 \mathrm{~cm}^{-1}$. The lower frequency has for some years been identified as a hindered translation, and the higher as a hindered rotation or libration of an isolated water molecule in the surrounding water (or ice) structure. Bernal and Tamm $^{6}$ estimated these frequencies as 170 and $480 \mathrm{~cm}^{-1}$ in ice, and used them to calculate the specific heat of ice at the melting point. 